\title{
Evaluating of chlorpyrifos-degrading by bacterial strains in mineral salt minimum and in the soil
}

\author{
Truong Quoc Tat ${ }^{*}$, Duong Minh Vien ${ }^{2}$ \\ ${ }^{1}$ Faculty of Agriculture and Food Technology, Tien Giang University, Vietnam \\ ${ }^{2}$ College of Agriculture and Applied Biology, Can Tho University, Vietnam \\ *Corresponding author: truongquoctat@tgu.edu.vn
}

\begin{tabular}{|c|c|}
\hline ARTICLE INFO & ABSTRACT \\
\hline $\begin{array}{l}\text { DOI:10.46223/HCMCOUJS. } \\
\text { tech.en.10.1.358.2020 }\end{array}$ & $\begin{array}{l}\text { Four bacterial strains degraded chlorpyrifos, isolated from } \\
\text { agricultural soil, were used as a source of bacteria to investigate } \\
\text { their ability to decompose chlorpyrifos in mineral salt minimum } \\
\text { and the soil. Barrientosimonas humi C4.3 was investigated for the } \\
\text { decomposition of chlorpyrifos in this strain on different days ( } 10 \text {, } \\
20 \text { and } 30 \text { days of culture) as supplemented and not supplemented } \\
\text { TSB. At the same time, another experiment was carried out to }\end{array}$ \\
\hline Received: October 1 1, 2019 & evaluate the chlorpyrifos etherification of B. humi C4.3 and the \\
\hline Revised: November $4^{\text {th }}, 2019$ & four strains of Achromobacter xylosoxidans C3.1, B. humi C4.3, \\
\hline Accepted: November $21^{\text {st }}, 2019$ & $\begin{array}{l}\text { Microbacterium sp. C8.9, Staphylococcus pasteuri C9.2 in a soil } \\
\text { environment. The experiment was carried out including } 3 \\
\text { treatments, each treatment was repeated 3, two soil types (sterile } \\
\text { soil and non-sterile soil) and bacteria (single bacteria and four } \\
\text { bacterial species). The results showed that, in the same culture } \\
\text { period of } 30 \text { days incubation, biodegradable chlorpyrifos of B. } \\
\text { humi C4.3 in the mineral salt medium was more effective ( } 63.07 \%\end{array}$ \\
\hline $\begin{array}{l}\text { Keywords: } \\
\text { agricultural soil, bacteria, } \\
\text { Barrientosimonas humi C4., } \\
\text { chlorpyrifos }\end{array}$ & $\begin{array}{l}\text { biodegradable chlorpyrifos) than when grown in soil ( } 21.4 \% \\
\text { biodegradable chlorpyrifos). Also, biodegradable chlorpyrifos of } \\
\text { B. humi C } 4.3 \text { that was cultured in sterile soil was higher than in } \\
\text { non-sterile soil. }\end{array}$ \\
\hline
\end{tabular}

\section{Introduction}

Application of the pesticide on the crops is now a common practice and is an important factor of integrated pest management (IPM) strategies. It adversely affects the properties of the soil as well as alters the $\mathrm{pH}$ of the soil required for microbial activities of beneficial bacteria to act upon (Malinowski, 2000; Rahman \& Motoyama, 2000). Some of these pesticides persist in the soil to form pollutants which may occasionally lead to surface and groundwater contamination. One of such pesticides is Chlorpyrifos. It is a broad-spectrum organophosphate insecticide and acaricide, which is widely used to control insect pests on grain, cotton, fruit, nut, and vegetable crops, as well as lawns and ornamental plants in Vietnam. The environmental fate of Chlorpyrifos has been studied extensively, and the reported half-life in the soil varies from 10 to120 days, with 3,5,6-trichloro-2-pyridinol (TCP) as the major degradation product 
(Singh, Walker, Morgan, \& Wright, 2003). The manufacture and formulation process of Chlorpyrifos also generate waste that contains the compound, and this has to be treated by physicochemical or biological means (Fulekar \& Geetha, 2008). If Chlorpyrifos is not degraded or detoxified rapidly enough, the risk of their off-site migration may pose a health risk to humans. Increasing awareness of the potential adverse effects of pesticides has resulted in greater public pressure to assess, monitor and minimize off-site impacts. Enhanced degradation of chlorpyrifos by Enterobacter strain B-14 was reported by (Singh, Walker, Alum, Morgan, \& Wright, 2004). Alkaligenes faecalis DSP3 was isolated, which is capable of degrading chlorpyrifos and 3, 5, 6-trichloro-2-pyridinol (TCPy) (L. Yang, Zhao, Zhang, Yang, \& Zhang, 2005). Six chlorpyrifos-degrading bacteria were isolated using chlorpyrifos as the sole carbon source by an enrichment procedure (C. Yang, Liu, Guo, \& Qiao, 2006). One research has isolated four strains of bacteria from agricultural soil capable of decomposing chlorpyrifos in minimum mineral solution (Truong, Nguyen, \& Duong, 2016). Therefore, to compare and evaluate the ability of four bacteria strains to disintegrate the chlorpyrifos in the minimum mineral solution and in the soil to provide more compelling data to be able to apply the potential bacterial strains practicality in the treatment of soil environmental pollution.

\section{Materials and methods}

\subsection{Materials}

Soil samples used in this experiment were taken at depths from $0-20 \mathrm{~cm}$ from acid sulfate soil of paddy rice at Phung Hiep district, Hau Giang province. Soil characteristics: Clay 57\%; Loam 42\%; Sand 1\%; Organic content $4.87 \%$ and $\mathrm{pH} 4.5$. The soil used in the experiment are dried at room temperature, finely ground through a sieve $0.1 \mathrm{~mm}$ to create uniformity for processing soil samples and soil moisture at $60 \%$ by adding mineral salt minimum solution sterilized.

Chlorpyrifos ethyl (99,5\%, Dr.Ehrenstorfer), Tryptose Soybean Agar (TSA), Acetone $(99,8 \%)$, Toluen $(99,9 \%)$.

Mineral Minimal Medium: 870mLQ-water, 25mL buffer solution (35 gram $\mathrm{Na}_{2} \mathrm{HPO}_{4} .2 \mathrm{H}_{2} \mathrm{O}, 4$ gram $\left.\mathrm{KH}_{2} \mathrm{PO}_{4}\right), 100 \mathrm{~mL}$ mineral salt solution $\left[10\right.$ gram $\left(\mathrm{NH}_{4}\right) 2 \mathrm{SO}_{4}, 2$ gram $\mathrm{MgCl}_{2} .6 \mathrm{H}_{2} \mathrm{O}, 1$ gram $\left.\mathrm{Ca}(\mathrm{NO} 3)_{2} .4 \mathrm{H}_{2} \mathrm{O}\right], 5 \mathrm{~mL}$ trace element.

\subsection{Methods}

2.2.1. Experiment 1: Evaluating of aerobic digestion chlorpyrifos by bacterial strain (PH_C4.3) in mineral salt minimum

The aim of the experiment is survey decomposition chlorpyrifos of bacterial strain (PH_C4.3) in temperatures, $\mathrm{pH}$ appropriate to evaluate the chlorpyrifos decomposition rate of bacterial strain (PH_C4.3) in different days (10, 20 and 30 days of culture) as supplemented and not supplemented TSB. The experiment was carried out including 3 treatments, each treatment was repeated 3 , the components of each treatment are presented in Table 1. 


\section{Table 1}

The components of experiment 1 design

\begin{tabular}{cll}
\hline Treatments & \multicolumn{1}{c}{ Ingredient } & \multicolumn{1}{c}{ Target tracking } \\
\hline Control & $\begin{array}{l}\text { 4mL of mineral minimal medium, 20mg/L of } \\
\text { chlorpyrifos }\end{array}$ & \\
\hline 1 & $\begin{array}{l}3,9 \mathrm{~mL} \text { of mineral minimal medium, 20mg/L of } \\
\text { chlorpyrifos, } 100 \mu \mathrm{L} \text { of bacteria strain }\left(10^{6}\right.\end{array}$ & $\begin{array}{l}\text { Chlorpyrifos of content } \\
\text { and density of bacteria at } \\
\text { the time of } 0,10,20 \text { and }\end{array}$ \\
& cells/mL). & $\begin{array}{l}30 \text { days after incubation } \\
\text { culture }\end{array}$ \\
\hline 2 & $\begin{array}{l}3,85 \mathrm{~mL} \text { of mineral minimal medium, 20mg/L of } \\
\text { chlorpyrifos, } 100 \mu \mathrm{L} \text { of bacteria strain }\left(10^{6}\right. \\
\text { cells } / \mathrm{mL}), 50 \mu \mathrm{L} \text { of TSB }(0,5 \%) .\end{array}$ \\
\hline
\end{tabular}

Source: The researcher's data analysis

The experiment was arranged at $30^{\circ} \mathrm{C}, \mathrm{pH} 7$ and mix continuously for up to the speed of $130 \mathrm{rpm}$.

2.2.2. Experiment 2: Evaluating of aerobic digestion chlorpyrifos by bacterial strain (PH_C4.3) and four bacterial strains (PH_C3.1, PH_C4.3, BM_C9.2, and BT_C8.9) in soil

The experiment was carried out to evaluate aerobic digestion chlorpyrifos by bacterial strain (PH_C4.3) and four bacterial strains (PH_C3.1, PH_C4.3, BM_C9.2, and BT_C8.9) in soil. Soil samples used in this experiment were taken at depths from $0-20 \mathrm{~cm}$ from acid sulfate soil of paddy rice at Phung Hiep district, Hau Giang province (soil samples used to isolate bacterial strain PH_C4.3). Soil characteristics: Clay 57\%; Loam 42\%; Sand 1\%; Organic content $4.87 \%$ and $\mathrm{pH} 4.5$. The soil used in the experiment was dried at room temperature, finely ground through a sieve $0.1 \mathrm{~mm}$ to create uniformity for processing soil samples and soil moisture at $60 \%$ by adding mineral salt minimum solution sterilized.

The experiment was arranged in a vial $(12 \mathrm{~mL})$ with 5 treatments, two factors were examined two soil types (sterile and non-sterile) and bacteria (one bacterial strain and four bacterial strains), each treatment was repeated 3 times. The components of each treatment are presented in Table 2.

\section{Table 2}

The components of experiment 2 design

\begin{tabular}{clc}
\hline Treatments & \multicolumn{1}{c}{ Ingredient } & $\begin{array}{c}\text { Target } \\
\text { tracking }\end{array}$ \\
\hline 1-Control & $3 \mathrm{~g}$ for sterile soil, $20 \mathrm{mg} / \mathrm{L}$ for chlorpyrifos & \\
\hline & $\begin{array}{l}3 \mathrm{~g} \text { for sterile soil, } 20 \mathrm{mg} / \mathrm{L} \text { for chlorpyrifos, } 200 \mu \mathrm{L} \text { for bacterial } \\
\text { strain-PH_C } 4.3\left(10^{6} \mathrm{cells} / \mathrm{mL}\right)\end{array}$ & $\begin{array}{c}\text { Content of } \\
\text { Chlorpyrif }\end{array}$ \\
\hline 3-Control & $3 \mathrm{~g}$ for non-sterile soil, $20 \mathrm{mg} / \mathrm{L}$ for chlorpyrifos & \\
\hline
\end{tabular}




\begin{tabular}{clc}
\hline Treatments & \multicolumn{1}{c}{ Ingredient } & $\begin{array}{c}\text { Target } \\
\text { tracking }\end{array}$ \\
\hline & $\begin{array}{l}3 \mathrm{~g} \text { for non-sterile soil, } 20 \mathrm{mg} / \mathrm{L} \text { for chlorpyrifos, } 200 \mu \mathrm{L} \text { for bacterial } \\
\text { strain-PH_C4.3 }\left(10^{6} \text { cells/mL }\right)\end{array}$ & $\begin{array}{c}\text { os in the } \\
\text { soil at the } \\
\text { time of } 30\end{array}$ \\
4 & $\begin{array}{l}3 \mathrm{~g} \text { for non-sterile soil, } 20 \mathrm{mg} / \mathrm{L} \text { for chlorpyrifos, } 50 \mu \mathrm{L} \text { for each } \\
\text { days after } \\
\text { bacterial strain } \\
\left(10^{6} \text { cells/mL). }\right.\end{array}$ & $\begin{array}{c}\text { incubation } \\
\text { culture }\end{array}$ \\
&
\end{tabular}

Source: The researcher's data analysis

The vial was vortex with speed $2000 \mathrm{rpm}$ to the ingredients in a vial and exposed are distributed together. Bacteria in the sample were incubated at room temperature experiments $\left(30^{\circ} \mathrm{C}\right)$ and let stand. After 30 days of culture incubation, chlorpyrifos in the incubated soil samples was extracted, cleaned and analyzed. The content of Chlorpyrifos is determined on HPLC.

\subsubsection{Methods of analysis and data processing}

The data were processed using Microsoft Excel, Minitab 16 Statistical Software to analyze statistics and ANOVA.

\section{Results and discussion}

\subsection{Evaluating of aerobic digestion chlorpyrifos by bacterial strain (Barrientosiimonas humi C4.3) in mineral salt minimum}

The average density of the bacterial strain (Barrientosimonas humi C4.3) was presented in Figure 1.

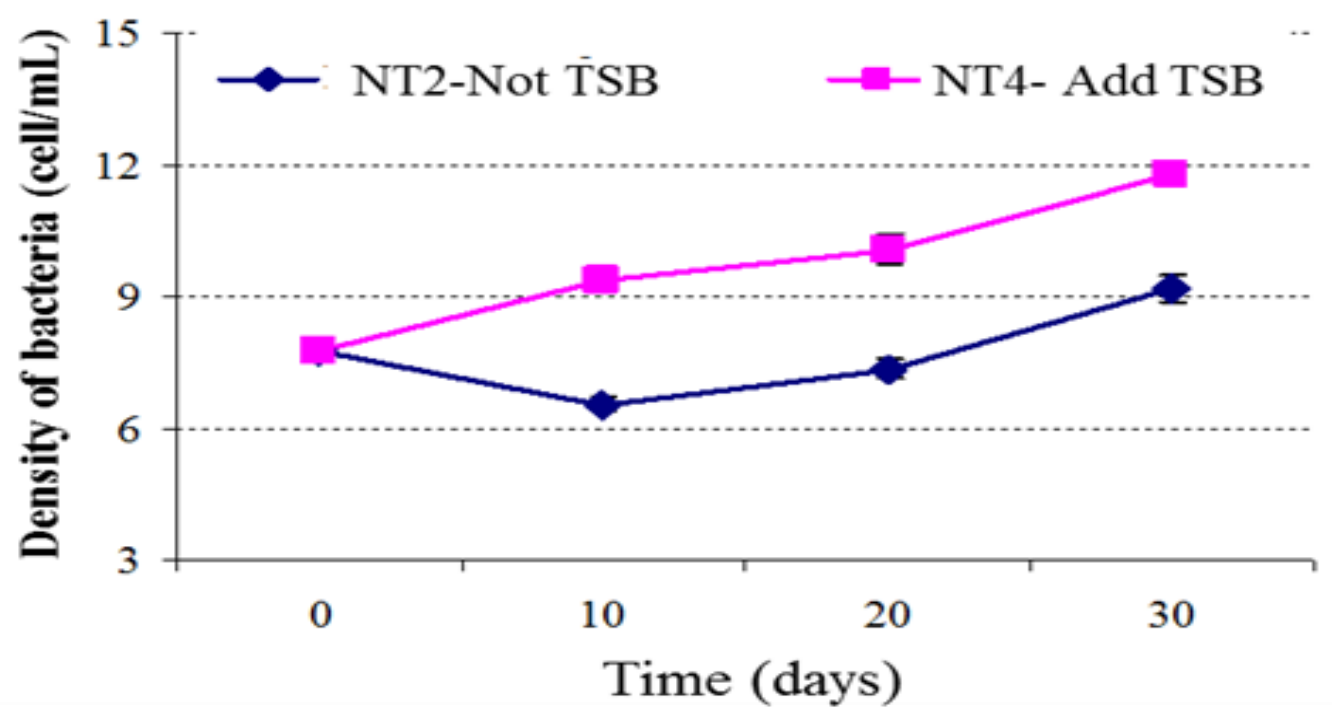

Figure 1. Density of Barrientosimonas humi C4.3

Besides TSB treatments, bacterial cell density higher than the density of the bacterial cells were always cultured in supplemented TSB environment. 
Biodegradable chlorpyrifos, for no additional treatments TSB 30 days to the time remaining content of chlorpyrifos $(6.8 \mathrm{ppm})$, decreased by $12.1 \mathrm{ppm}(63.7 \%)$ and the difference was statistically significant compared to control. For additional treatments TSB, the time of 30 days remaining content of chlorpyrifos the difference was not statistically significant compared to control (Figure 2).

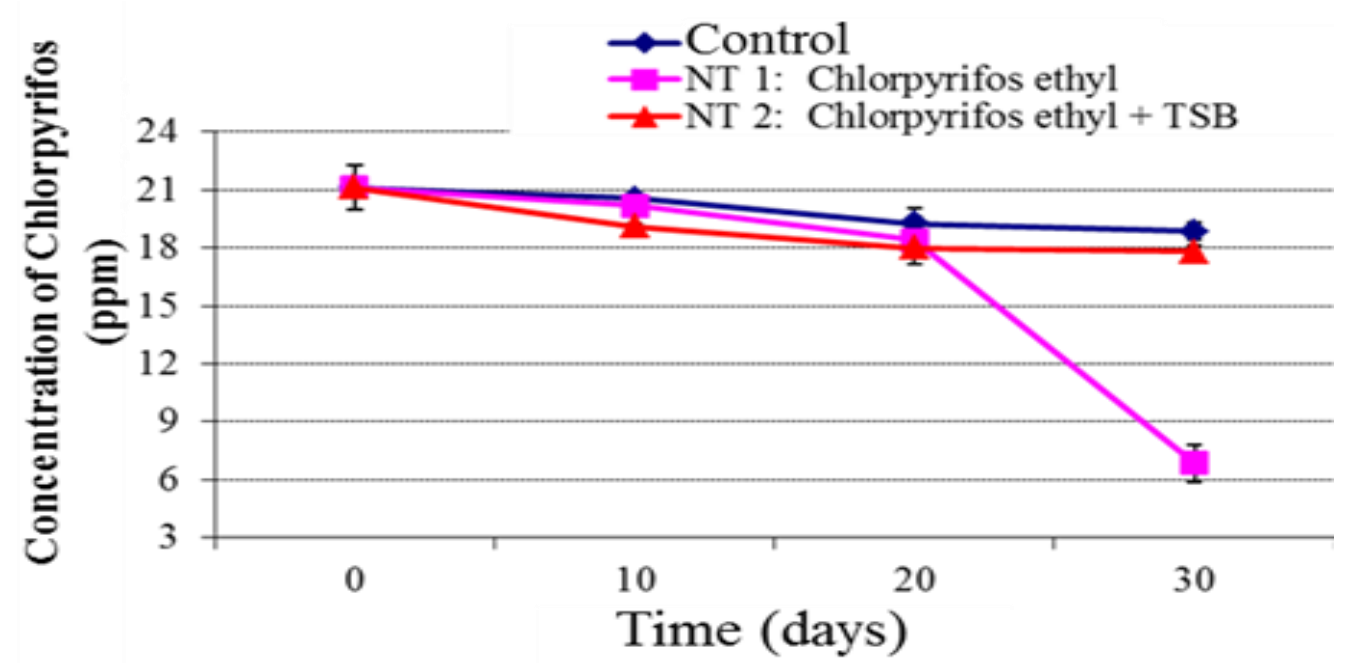

Figure 2. Biodegradable chlorpyrifos of Barrientosimonas humi C4.3

\subsection{Evaluating of aerobic digestion chlorpyrifos by bacterial strains} (Barrientosiimonas humi C4.3) and four bacterial strains in soil

After 30 days of culture incubated, Barrientosimonas humi C4.3 degraded chlorpyrifos in the two types of soil. On the other hand, when four bacterial strains were added to non-sterile soil, the level of biodegradable increased (28.4\%) in comparison to single bacteria Barrientosimonas humi C4.3 (19.3\%) (Figure 3).

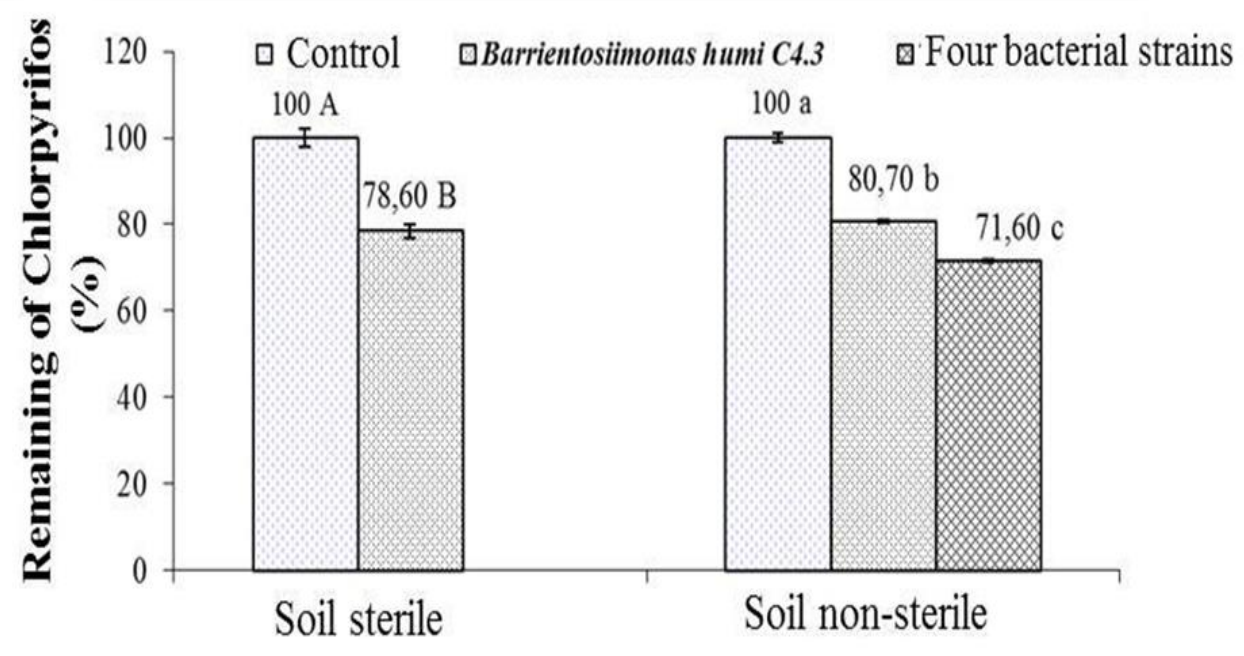

Figure 3. Biodegradable of chlorpyrifos of Barrientosimonas humi $\mathrm{C} 4.3$ and bacterial groups Notes-Four bacterial strains include: Achromobacter xylosoxidans C3.1, Barrientosiimonas humi C4.3, Microbacterium sp. C8.9, Staphylococcus pasteuri C9.2 
Thus, in the same culture period of 30 days incubation, biodegradable chlorpyrifos of Barrientosimonas humi $\mathrm{C} 4.3$ in the mineral salt medium was more effective $(63.07 \%$ biodegradable chlorpyrifos) than when grown in soil (21.4\% biodegradable chlorpyrifos). Also, biodegradable chlorpyrifos of Barrientosimonas humi C4.3 when cultured in sterile soil was higher than in non-sterile soil.

\section{Conclusions}

Biodegradable chlorpyrifos of $B$. humi $\mathrm{C} 4.3$ in the mineral salt medium was more effective than when grown in soil. Besides that, biodegradable chlorpyrifos of B. humi C4.3 when cultured in sterile soil was higher than in non-sterile soil.

\section{References}

Fulekar, M. H., \& Geetha, M. (2008). Bioremediation of Chlorpyrifos by Pseudomonas aeruginosa using scale up technique. Journal of Applied Bioscience, 12, 657-660.

Malinowski, H. (2000). Impact of more important factors on the activity of insecticide used in forest protection. I. Soil Insecticides. Sylwan, 144(9), 90-100.

Rahman, G. K. M. M., \& Motoyama, N. (2000). Determination of Chlorpyrifos residue in andosol upland soils using methanol phosphoric acid extraction. Journal of Pesticide Science, 25(4), 387-391.

Singh, B, K., Walker, A., Alum, J., Morgan, J. A., \& Wright, D. J. (2004). Biodegradation of chlorpyrifos by Enterobacter strain B-14 and its use in biodegradation of contaminated soils. American Society for Microbiology Journals, 70, 4855-4863. doi:10.1128/AEM.70.8.4855-4863.2004

Singh, B. K., Walker, A., Morgan, A. J., \& Wright, D. J. (2003). Effects of soil pH on the Biodegradation of Chlorpyrifos and Isolation of a Chlorpyrifos-Degrading bacterium. American Society for Microbiology Journals, 9, 5198-5206. doi:10.1128/aem.69.9.51985206.2003

Truong, Q. T., Nguyen, T. A. T., \& Duong, M. V. (2016). Isolation of chlorpyrifos ethyl degrading bacteria from continuous paddy rice soils over the Mekong delta. Science and Technology Journal of Agriculture and Rural Development, 9, 33-38.

Yang, L., Zhao, Y. H., Zhang, B. X., Yang, C. H., \& Zhang, X. (2005). Isolation and characterization of a chlorpyrifos and 3, 5, 6-trichloro-2-pyridino degrading bacterium. Federation of European Microbiological Societies Microbiol Letters, 251, 67-73. doi:10.1016/j.femsle.2005.07.031

Yang. C., Liu, N., Guo, X., \& Qiao, C. (2006). Cloning of mpd gene from chlorpyrifosdegrading bacterium and use of this strain in bioremediation of contaminated soil. Federation of European Microbiological Societies Microbiol Letters, 265, 118-125. doi:10.1111/j.1574-6968.2006.00478.x 